\title{
Changes in Tissue Oxidative Enzymes in Rats exposed to Red Bull Energy Drink and Alcohol
}

\author{
EKAKITIE, L; ASAGBA, SO; *ORORORO, OC \\ Department of Biochemistry, Faculty of Science, Delta State University Abraka, Nigeria \\ *Corresponding Author Email: osuvwec@yahoo.com; Tel: +2348062306783
}

\begin{abstract}
There is increase in combined ingestion of alcoholic beverages and energy drinks, but studies on their combined effects on tissue oxidative enzymes are limited. Hence, the present study examined the changes in tissue oxidative enzymes (aldehyde oxidase, AO, EC 1.2.3.1; xanthine oxidase, XO, EC 1.17.3.2; sulphite oxidase, SO, EC 1.8.3.1; and monoamine oxidase, MO, EC 1.4.3.4) in the liver, kidney, heart, brain and testes of rats exposed to red bull energy drink and ethanol. Twenty eight Wistar rats $(190 \pm 5 \mathrm{~g})$ were used for the study. The animals were divided into four groups. Group 1 which was fed with only grower's mash and water served as control. In addition to the normal dietand water rats in Group 2 receivedRed bull energy drink (3.5 $\mathrm{ml} / \mathrm{kg}$ body weight), while those in Group 3 received Ethanol $(1.25 \mathrm{~g} / \mathrm{kg}$ body weight) by intubation. Rats in Group 4 received bothred bull and ethanol as in Groups 2 and 3.Consumption of red bull significantly $(\mathrm{P}<0.05)$ decreased liver $\mathrm{AO}$ activity as compared to control. The results showed that red bull, ethanol or their combination had variable effects on tissue oxidative enzymes as alteration was observed in the activity of the oxidative enzymes. The effect of a combination of red bull and ethanol was more pronounced in the liver MO, kidney AO, liver XO and liver SO than either red bull or ethanol alone. In conclusion the present study has shown that consumption of red bull, ethanol or their combination may alter the ability of tissue oxidative enzymes to metabolize zenobiotics.
\end{abstract}

\section{DOI: https://dx.doi.org/10.4314/jasem.v23i6.27}

Copyright: Copyright (c) 2019 Ekakitie et al. This is an open access article distributed under the Creative Commons Attribution License (CCL), which permits unrestricted use, distribution, and reproduction in any medium, provided the original work is properly cited.

Dates: Received: 10 April 2019; Revised: 27 May 2019; Accepted 25 June 2019

Keywords: Oxidative enzymes, Energy drinks, Alcohol, Red Bull, Rat

The production and consumption of energy drinks is increasing worldwide as they are consumed heavily by teenagers, university students and athletes due to their ability to increase energy level and prevent sleep. They have also been reported to enhance physical performance, ease mental exhaustion and improve mood (Gheith, 2017; Kassab et al., 2018). These effects are attributed to the ingredients use in production of energy drinks such as carbohydrates, vitamins caffeine, L-carnitine, glucuronolactone, and herbal supplements (Munteanu et al., 2014). Red bull is a popular energy drink, which was launched in 1987.Previous studies have confirmed the harmful effects of energy drinks on several organs and tissues such as the cardiac muscle, kidney and liver (Khayyat et al., 2012; Bukhar et al., 2012;Taiwo et al., 2017). Munteanu et al. (2014) also showed that Red Bull affects certain morphological and biochemical blood parameters and is a risk factor for the development of metabolic diseases. Thus, researchers in recent times have raised concerns over the combination of alcohol, which has known toxic effects, with energy drinks (Rengin et al., 2017; Díaz et al., 2016; Ugwuja, 2014). McKetin et al. (2015) reported that using caffeine plus alcohol may enhance wakefulness and alertness, diminish alcohol-associated exhaustion and thus keep the desire to continue consumption. Alcohol and caffeine, the main ingredient in energy drinks are diuretics. According to Thombs et al. (2010), their combined ingestion can cause rapid dehydration in the body and make the consumer more prone to alcohol toxicity. Weldy (2010) reported that the consumption of energy drinks together with alcohol aids the increased absorption of alcohol into the bloodstream. Ingested alcohol and other zenobiotics present in energy drinks are biotransformed in the body by tissue metabolizing enzymes such as aldehyde oxidese (AO), xanthine oxidase (XO) and sulphite oxidase (SO), which occurs mainly in hepatic tissues (Moore, 2004). These oxidative enzymes play a great role in the detoxification of xenobiotics. However, studies on the effect of energy drinks alone and in combination with alcohol on tissue oxidative enzymes are scarce. Therefore, the aim of the present study was to determine the changes in tissue oxidative enzymes in rats exposed to red bull energy drink and alcohol.

\section{MATERIALS AND METHODS}

Experimental Animals: Twenty eight male Wistar rats with average body weight of $190 \pm 5 \mathrm{~g}$ were used for the 
study. They were obtained from the College of Health Sciences, Delta State University, Abraka and were housed in standard wooden cages in a room maintained at $25 \pm 2{ }^{\circ} \mathrm{C}$ with a $12 \mathrm{~h}$ light/anddark cycle. Acclimatization was for three weeks before the commencement of experiments and the rats were given free access to standard laboratory feed (Top feeds Ltd., Sapele, Delta State) and water ad libitum.

Other Materials: The cans of energy drink, 'Red Bull' manufactured by Red Bull GmbH, Austria were purchased within Abraka, Delta State, Nigeria and the ethanol used was from British Drug House, Poole, England. All other reagents and chemicals used in this study were of analytical grade.

Experimental Design: The animals were divided into four groups of seven rats each. Rats in Group 1 (control) were fed with growers mash and water only. In addition to water and grower's mash, rats in Groups 2 and 3 received Red bull energy drink $(3.5 \mathrm{ml} / \mathrm{kg}$ body weight) and Ethanol $(1.25 \mathrm{~g} / \mathrm{kg}$ body weight respectively. Rats in Group 4 were fed with growers mash and water and were administered red bull and ethanol with the same doses used in Groups 2 and 3 respectively. The ingestion was done through an intragastric tube three times a week for five weeks.

Collection of Plasma and Tissue Samples: At the end of the experimental period, rats were deprived of food overnight and sacrificed. The organs (brain, liver, testes, kidney and heart) of each rat were removed quickly, cleaned free of extraneous material and placed in labeled ice-cold containers. Ten percent homogenate of each organ was prepared under cold conditions using normal saline. The homogenate was centrifuged at $5000 \mathrm{~g}$ for 15 mins to separate the nuclear debris. The supernatant was collected into labeled containers for biochemical estimations.

Biochemical Assays: The activity of aldehyde oxidase (AO, EC.1.2.3.1)was determined by the method of Johns (1967) and was monitored based on the decrease in absorbance at $600 \mathrm{~nm}$ which is resultant of the oxidation of benzaldehyde to benzoate using 2, $6-$
Dichloroindophenol (DCIP) as electron acceptor. The activity of the enzymewas expressed in units per gramme tissue, one unit of the enzyme being the amount of the enzyme that produces one micromole of benzoate per minute. Monoamine oxidase (MO, EC.1.4.3.4) activity was assayed by the method proposed by Tabor et al (1954) based on the oxidative deamination of benzylamine to benzaldehyde. The activity of MO was given in units per gramme tissue, one unit of the enzyme being the amount of the enzyme that produced one micromole of benzaldehyde per minute. The activity of xanthine oxidase (XO, EC.1.17.3.2) was determined by the method of Dixon and Thurlow (1924) based on the XO-catalysed conversion of methylene blue to the reduced colourless form. Enzyme activity was taken as $1 /$ the time taken for methylene blue to change colourless. The activity of xanthine oxidase was expressed as min $^{-}$ ${ }^{1}$ per gramme wet tissue. Sulphite oxidase (SO, EC.1.8.3.1) activity was determined by the method of Macleod et al.(1961) based on the Sulphite oxidasecatalyzed oxidation of sulphite to sulphate with ferricytochrome $\mathrm{C}$ as physiological electron acceptor. One unit of the enzyme was defined as the amount of the enzyme that reduces one micromole of ferricyanide per minute.

Data Analysis: Results are presented as Mean \pm SEM. The mean values between the groups were compared by using analysis of variance (ANOVA) and differences in the means were tested by Least Significant difference test (LSD) with difference between means being considered to be significant at $\mathrm{p}<0.05$.

\section{RESULTS AND DISCUSSION}

The effect of red bull, ethanol and combination of both drinks on tissue AO activity is presented in Table 1. Consumption of red bull significantly $(\mathrm{P}<0.05)$ decreased liver AO activity as compared to control. However no significant difference was observed in the activity of $\mathrm{AO}$ in the liver of rats exposed to ethanol relative to control.

Table 1: The effect of combined and separate administration of ethanol and red bull on aldehyde oxidase activity in the tissues of experimental rats

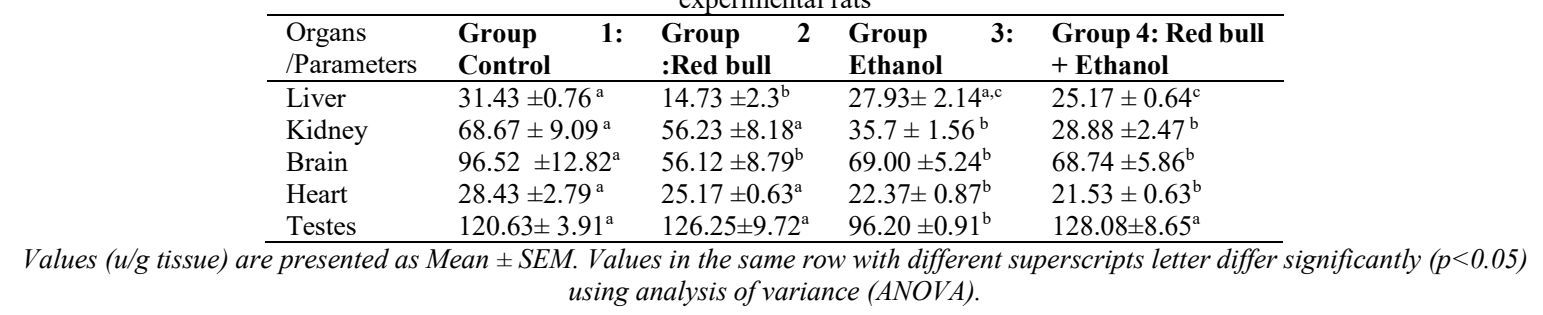


The concomitant exposure of rats to red bull and alcohol significantly decreased liver AO activity of rats relative to control. Examination of the data obtained showed that there was no significant difference in heart AO activity of rats that consumed red bull, but those that consumed alcohol or red bull plus alcohol had a significant $(\mathrm{P}<0.05)$ decrease relative to control. Kidney $\mathrm{AO}$ activity was not significantly $(\mathrm{P}>0.05)$ altered in rats treated with red bull, but was significantly decreased in those that consumed alcohol relative to control. Similarly the activity of the enzyme was significantly decreased in the kidney of rats that consumed both red bull and alcohol relative to control. There was a significant decrease in brain $\mathrm{AO}$ activity of rats administered red bull or ethanol relative to rats in control. The activity of the enzyme remained significantly decreased in rats administered red bull in addition to alcohol as compared to rats in the control group. The testes AO activity of rats administered red bull and red bull plus ethanol was not significantly $(\mathrm{P}>0.05)$ different from the rats in control. However, there was a significant decrease in the enzyme activity in rats administered ethanol only as compared to rats in control. Thus the study showed that red bull consumption influenced the effect of alcohol on liver AO and testis AO, but had no influence on alcohol induced effect on heart AO, kidney AO and brain AO.

Table 2 represents the effect of red bull, ethanol and combination of both drinks on tissue MO activity of experimental rats. The liver MO activity was not significantly different from control in rats treated separately with red bull and alcohol. However combined treatment with red bull plus alcohol significantly increased liver $\mathrm{MO}$ activity of rats relative to control. The kidney $\mathrm{MO}$ activity of rats administered red bull drink was significantly decreased relative to control. Conversely, rats administered alcohol had no significant difference in kidney MO relative control. Similarly rats administered both drink simultaneously had no significant $(\mathrm{P}>0.05)$ change in kidney MO activity relative to control. The $\mathrm{MO}$ activity in the heart of rats was not significantly $(\mathrm{P}>0.05)$ different from the control in rats treated with red bull. Conversely the heart MO activity of alcohol treated rats was significantly decreased relative to control. Like in red bull treated rats, no significant change was observed in heart MO activity of rats simultaneously treated with red bull and alcohol.

Table 2: The effect of combined and separate administration of ethanol and energy drinks on monoamine oxidase activity in the tissues of experimental rats

\begin{tabular}{|c|c|c|c|c|}
\hline $\begin{array}{l}\text { Organs } \\
\text { /Parameters }\end{array}$ & $\begin{array}{l}\text { Group } \\
\text { Control }\end{array}$ & $\begin{array}{l}\text { Group } \\
\text { bull }\end{array}$ & $\begin{array}{l}\text { Group } \\
\text { Ethanol }\end{array}$ & $\begin{array}{l}\text { Group 4: Red } \\
\text { bull +Ethanol }\end{array}$ \\
\hline Liver & $110.20 \pm 17.59^{a}$ & $121.18 \pm 14.45^{\mathrm{a}}$ & $111.04 \pm 22.22^{\mathrm{a}}$ & $224.16 \pm 13.75^{b}$ \\
\hline Kidney & $52.29 \pm 4.61^{\mathrm{a}}$ & $39.58 \pm 2.29^{b}$ & $48.95 \pm 3.09^{\mathrm{a}}$ & $52.91 \pm 1.44^{\mathrm{a}}$ \\
\hline Brain & $61.82 \pm 7.65^{\mathrm{a}}$ & $34.82 \pm 2.0^{\mathrm{b}}$ & $37.84 \pm 2.71^{\mathrm{b}}$ & $68.56 \pm 7.39^{\mathrm{a}}$ \\
\hline Heart & $82.08 \pm 9.98^{\mathrm{a}}$ & $94.03 \pm 15.88^{\mathrm{a}}$ & $46.88 \pm 8.05^{b}$ & $70.55 \pm 6.34^{\mathrm{a}}$ \\
\hline Testes & $58.38 \pm 5.3^{\mathrm{a}}$ & $49.15 \pm 10.16^{\mathrm{a}}$ & $72.25 \pm 7.17^{b}$ & $73.65 \pm 6.94^{b}$ \\
\hline
\end{tabular}

Table 3: The effect of separate and combined effect of ethanol and energy drinks on Xanthine oxidase activity in the tissues of experimental rats

\begin{tabular}{llllll}
\hline $\begin{array}{l}\text { Organs } \\
\text { /Parameters }\end{array}$ & $\begin{array}{l}\text { Group } \\
\text { Control }\end{array}$ & $\begin{array}{l}\text { Group 2 :Red } \\
\text { bull }\end{array}$ & $\begin{array}{l}\text { Group } \\
\text { Ethanol }\end{array}$ & $\begin{array}{l}\text { 3: Group 4: Red } \\
\text { bull +Ethanol }\end{array}$ \\
\hline Liver & $14.05 \pm 0.009^{\mathrm{a}}$ & $4.08 \pm 0.024^{\mathrm{b}}$ & $5.05 \pm 0.03^{\mathrm{c}}$ & $4.32 \pm 0.011^{\mathrm{d}}$ \\
Kidney & $25.82 \pm 1.39^{\mathrm{a}}$ & $13.22 \pm 1.89^{\mathrm{b}}$ & $30.61 \pm 0.51^{\mathrm{c}}$ & $25.87 \pm 1.51^{\mathrm{a}}$ \\
Brain & $63.69 \pm 3.38^{\mathrm{a}}$ & $82.3 \pm 8.23^{\mathrm{b}}$ & $70.36 \pm 8.99^{\mathrm{a}}$ & $71.08 \pm 6.67^{\mathrm{a}}$ \\
Testes & $118.51 \pm 52.5^{\mathrm{a}}$ & $117.84 \pm 45.90^{\mathrm{a}}$ & $141.77 \pm 29.17^{\mathrm{a}}$ & $124.73 \pm 10.03^{\mathrm{a}}$ \\
Heart & $24.19 \pm 0.88^{\mathrm{a}}$ & $24.19 \pm 0.09^{\mathrm{a}}$ & $22.08 \pm 0.03^{\mathrm{b}}$ & $30.14 \pm 0.023^{\mathrm{b}}$ \\
\hline
\end{tabular}

Values ( $/ \mathrm{g}$ tissue) are presented as Mean \pm S.D values in the same row with different superscripts letter differ significantly ( $p<0.05$ ) using analysis of variance (ANOVA).

Consumption of red bull or alcohol significantly decreased brain MO activity relative to Control. However no significant $(\mathrm{P}>0.05)$ difference was observed in the activity of brain $\mathrm{MO}$ in rats exposed to a combination of ethanol and red bull. The data obtained also showed that there was no significant difference in testes MO activity of rats that consumed red bull when compared to control. Conversely the testes MO activity of alcohol treated rats was significantly increased relative to control. Significant increase was also observed on testes MO activity of rats simultaneously treated with red bull and alcohol relative to control. Thusthe study revealed that administration of red bull to alcohol treated rats did not influence the effect of alcohol on kidney and testes MO activity. The effect of red bull, ethanol and combination of both drinks on tissue XO activity of experimental rats is presented in Table 3. The liver XO 
activity was significantly decreased in rats exposed to red bull, ethanol and the combination of both red bull and ethanol when compared to the control. The kidney $\mathrm{XO}$ activity decreased significantly in rats exposed to red bull, relative to control, but those treated with alcohol had a significantly increased kidney XO activity. However, the kidney $\mathrm{XO}$ activity of rats treated simultaneously with red bull and ethanol was not significantly different relative to control. The heart $\mathrm{XO}$ activity showed no significant difference in rats exposed to red bull, relative to control. Conversely, those treated with ethanol had a significantly decreased XO activity relative to control. However, rats exposed to the combination of both red bull and ethanol showed a significantly increased XO activity. The brain XO activity of rats treated with red bull was significantly increased from the control, but those treated with ethanol had no significant difference relative to control. Similarly, the brain XO activity of rats administered a combination of both drinks, had no significant difference relative to control. Hence administration of red bull did not influence the effect of alcohol on brain XO activity. The testes XO activity of rats treated with red bull, ethanol or their combination was not significantly different from the control. Table 4 represents the effect of red bull, ethanol and combination of both drinks on tissue SO activity of experimental rats. The result obtained showed that both red bull and alcohol significantly increased liver SO activity of rats. The coadministration of both drinks to rats also significantly increased liver SO activity. However the liver SO activity of rats that consumed both red bull and ethanol was significantly higher than that of rats which consumed either ethanol or red bull. Kidney SO was not significantly different in rats treated with red bull relative to control. Conversely, rats treated with ethanol had a significantly decreased kidney SO activity relative to control. The kidney SO activity remained significantly decreased in ethanol treated rats even after the combination with red bull. Heart SO activity was significantly decreased in rats treated with ethanol, red bull or their combination relative to control. However, there was no significant difference in the SO activity in brain of rats treated with red bull, ethanol and their combination relative to control. Similarly the testis SO activity was not significantly different in rats treated with red bull or a combination of red bull and ethanol. Conversely ethanol treated rats had a significantly increased testis SO activity.

Table 4.The effect of combined and separate effect of red bull and ethanol on tissue sulphite oxidase (SO) activity of rats

\begin{tabular}{lllll}
\hline $\begin{array}{l}\text { Organs } \\
\text { /Parameters }\end{array}$ & $\begin{array}{l}\text { Group } \\
\text { Control }\end{array}$ & $\begin{array}{l}\text { Group 2:Red } \\
\text { bull }\end{array}$ & $\begin{array}{l}\text { Group3: } \\
\text { Ethanol }\end{array}$ & Group 4: Red bull +Ethanol \\
\hline Liver & $75.87 \pm 5.99^{\mathrm{a}}$ & $97.58 \pm 13.59^{\mathrm{b}}$ & $82.5 \pm 5.16^{\mathrm{c}}$ & $133.82 \pm 14.4^{\mathrm{d}}$ \\
Kidney & $114.58 \pm 46.2^{\mathrm{a}}$ & $199.46 \pm 63.5^{\mathrm{a}}$ & $67.62 \pm 13.3^{\mathrm{b}}$ & $79.74 \pm 6.9^{\mathrm{c}}$ \\
Brain & $63.69 \pm 3.38^{\mathrm{a}}$ & $82.3 \pm 8.23^{\mathrm{a}}$ & $70.36 \pm 8.99^{\mathrm{a}}$ & $71.08 \pm 6.67^{\mathrm{a}}$ \\
Heart & $160.67 \pm 24.3^{\mathrm{a}}$ & $79.98 \pm 9.3^{\mathrm{b}}$ & $81.22 \pm 9.2^{\mathrm{b}}$ & $125.63 \pm 17.6^{\mathrm{c}}$ \\
Testes & $118.51 \pm 52.5^{\mathrm{a}}$ & $117.84 \pm 45.90^{\mathrm{a}}$ & $141.77 \pm$ & $124.73 \pm 10.03^{\mathrm{a}}$ \\
& & & $29.17^{\mathrm{a}}$ & \\
\hline
\end{tabular}

Values (u/g tissue) are presented as Mean $\pm S . D$ values in the same row with different superscripts letter differ significantly $(p<0.05)$ using analysis of variance (ANOVA).

In this study, the effects of ethanol and/ or red bull and their combination on the activities of selected tissue oxidative enzymes ( $\mathrm{SO}, \mathrm{XO}, \mathrm{MO}$, and $\mathrm{AO}$ ) were examined. These enzymes are missing play vital roles in the biotransformation of xenobiotics. $\mathrm{MO}$ is involved in the metabolism of tryptophan, tyramine, other amines as well as many drugs including caffeine. According to Asagba (2010), monoamine oxidase is also very useful in the biotransformation of aromatic monoamines, including neurotransmitters such as serotonin, adrenalin, histamine and dopamine. Similarly $\mathrm{AO}$ and $\mathrm{XO}$, which are molybdenum hydroxylases, play important roles in the metabolism of many exogenous and endogenous compounds such as aldehydes, nitro, sulfoxide, $\mathrm{N}$-oxide and other moieties (Kitamura et al., 2006). XO is also greatly involved in purine catabolism, where it aids the oxidation of hypoxanthine to uric acid via xanthine, (Kitamura et al., 2006). SO is involved in the metabolism of sulphur containing biomolecules such as glutathione and metallothionein, which are very essential in mopping up free radicals and preventing oxidative stress. The present study has shown that energy drink alone or in combination with ethanol has variable effects on these oxidative enzymes. Thus, the alteration observed in the activity of AO (Table 1), MO (Table 2), XO (Table 3) and SO (Table 4) in the tissues of rats treated with red bull, ethanol or their combination would influence their role in the detoxification of xenobiotic sand other aspects of metabolism. This will in turn aggravate the toxic effects of red bull or/and ethanol. Examination of all the data obtained in the present study indicates that a combination of red bull and ethanol was more adverse than either red bull or alcohol alone. This is evident in kidney AO (Table 1), liver MO (Table 2), liver XO (Table 3) and liver SO (Table 4). With this results, it can be stated that chemical synergism between some 
of the components of red bull and ethanol may account for the pronounced biochemical effects in rats offered both drinks. This is not surprising as studies using laboratory animals have demonstrated an interaction between alcohol and some components of energy drinks, especially taurine and caffeine (Kunin, et al., 2000; Lignori et al, 2001).

Conclusion: The results obtained suggest that combining energy drinks with alcohol as practiced by young people may exacerbate the effects of alcohol on oxidative enzymes. Thus the present findings may have public health implications for those that are forming the habits of combining energy drinks with erroneous belief that it ameliorates the effects of alcohol.

\section{REFERENCES}

Díaz A; Treviño, S; Guevara, J; Guadalupe, M; Eduardo, B; Blanca, E; Albino M; Gustavo, L; Ulises, P; Berenice, V; Anabella, H; Luis, M; Gonzalo, F; Patricia A (2016). Energy Drink Administration in Combination with Alcohol Causes an Inflammatory Response and Oxidative Stress in the Hippocampus and Temporal Cortex of Rats. Oxidative Med. Cellular Long.; 2016, Article ID 8725354, 1-9

Amira, AK; Sadika, MT (2018). Effect of a caffeinated energy drink and its withdrawal on the submandibular salivary gland of adult male albino rats: A histological and immunohistochemical study.EHX J. DOI: 10.21608/EJH.2018.7518

Asagba, SO (2010). Alteration in the activity of oxidative enzymes in the tissues of male wistar albino rats exposed to cadmium. Inter. J. Occup. Med. Environ. Health. 23(1):55 - 62

Bukhar, HM; El-Sawy, NA; Header, AE (2012). Biological effect of high energy drink on normal and hyperglycemic rats. Pak. J. Nutr. 11: 301-309.

Gheith, IM. (2017). Clinical Pathology of caffeinated and non-caffeinated energy drinks: Review. Life Sci. J. 14(9):21-36

Johns, DG (1967) Human liver aldehyde oxidase: differential inhibition of oxidation of charged and uncharged substrates. J. Clin. Invest. 46:1492-1505

Khayyat, L; Sorour, J; Al Rawi, M; Essawy, A (2012). Histological, ultrastructural and physiological studies on the effect of different kinds of energy drinks on the liver of swiss albino rat. J. Ame. Sci. 8: 688-697
Kitamura, S; Sugihara, K; Ohta, S (2006). Drug metabolizing ability of molybdenum hydroxylases. Drug Metab. Pharmacokinet. 21 (2): 83-98.

Kunin, D; Gaskin, S; Rogan, F; Smith, BR; Amit, Z (2000). Caffeine promotes ethanol drinking in rats. Examination using a limited-access free choice paradigm. Alcoholism.21:271-277

Liguori, A; Robinson, JH (2001). Caffeine antagonism of alcohol-induced driving impairment. Drug and AlcDepene. 63, 123-129

Macleod, RM; Farkas, W; Fridovich, I; Handler, P (1961). Purification and properties of hepatic sulphite oxidase. J. Biol. Chem. 236:1841-1846

McKetin, R; Coen, A; Kaye, S (2015). A comprehensive review of the effects of mixing caffeinated energy drinks with alcohol. Drug Alc. Dep. 151(6):15-30.

Moore, MR (2004). A commentary on the impacts of metals and metalloids in the environment upon the metabolism of drugs and chemicals. Toxicol. Lett. 148:153-158

Munteanu, C; Ioan, U; Corina, R; Camelia, L (2014). Chronic administration of red bull affects blood parameters in rats. Studia Universitatis Babeş - Bolyai, Biologia, LIX, 2: 89-98.

Rengin, R; Mohammad, C; Hande, S; Asiye, I; Do־gan, E; Macit, H; Ahmet, Aydın (2017). Energy Drink Induced Lipid Peroxidation and Oxidative Damage in Rat Liver and Brain When Used Alone or Combined with Alcohol. J. Food Sci.2017:1-7

Tabor, CW; Herbert, T; Sanford, MR (1954).Purification of amine oxidase from beef plasma. J. Bio. Chem.; 208:645-662.

Taiwo, OI; Adesokan, AA (2017). Effects of High Doses of Exogenous Taurine, Caffeine, and Taurine-Caffeine Combination on Biochemical, Haematological and Histologic Parameters of Adult Rabbits. Am. J. Biochem. 7(4): 63-72

Thombs, DL; O'Mara, RJ; Tsukamoto, M; Rossheim, ME; Weiler, RM; Merves, ML; Goldberger, BA (2010). Event-level analyses of energy drink consumption and alcohol intoxication in bar patrons. Add. Beh. 35(4), 325-330.

Ugwuja, EI (2014). Biochemical Effects of Energy Drinks Alone or in Combination with Alcohol in Normal Albino Rats. Adv. Pharm. Bulletin. 4(1), 69-74. 